\title{
Introduction: Land Claims in Latin America
}

Introducción: reclamos territoriales en América Latina

In memory of our dear friend and colleague,

Gerhard Øverland (1964-2014)

\section{ALEJANDRA MANCILLA}

Universidad de Oslo, Noruega

\section{CHRISTIAN BARRY}

School of Philosophy, Australian National University

Conflicts due to unresolved land claims are a pressing political and social issue throughout Latin America. From 2011 until 2014, the project "Who Owns It? Land Claims in Latin America: Their Moral Legitimacy and Implications," spearheaded by Gerhard Øverland and financed by the Norwegian Research Council, sought to evaluate the moral legitimacy of land claims by both indigenous and non-indigenous communities in different Latin American countries, and to normatively assess the means that these communities have adopted (or may adopt) to vindicate such claims. This special issue of Revista de Ciencia Política contains a select group of articles reflecting different theoretical and methodological approaches to these issues that were presented at the conference hosted by the project in Bogotá, Colombia, in August 2013.

While the first three papers inquire into the normative principles required to understand and to deal with land conflicts in Latin America, the last one examines a specific case study; namely, the fight for recognition of a Peruvian indigenous group, the Cañarenses, amidst the state's attempt to exploit the mineral resources in their territory.

In "Who owns it? Three Arguments for Redistribution of Land in Latin America," Gerhard Øverland and Christian Barry describe the extent to which the moral justification of land claims in Latin America remains under-explored, and propose a framework with which to evaluate them. As the authors suggest, these claims may be divided in roughly three types based on the moral reasons to which they appeal. Assistance-based claims emphasize that certain agents (such as the State, co-citizens, etc.) have a moral responsibility to help those who suffer severe harm at no fault of their own when the benefits of their actions are likely to be significant and the cost to such agents will be moderate. Contributionbased claims appeal to the idea that agents (typically the State) have stringent and demanding responsibilities to rectify past or ongoing injustice insofar as 
they have contributed or are contributing to it. Benefitting-based claims, lastly, propose that agents have moral responsibility to address injustices that they have benefited or are benefiting from. Because these different types of claim give rise to different types of duties, it is important to distinguish between them when looking at particular conflicts.

Starting from an assessment of two prominent types of liberal theories of territorial rights, Avery Kolers proposes in his contribution, "Latin America in Theories of Territorial Rights," that neither answers the question of "who owns it" satisfactorily. Kantian theories, on the one hand, base territorial claims on authoctony: namely, the idea that individuals simply happen to be in a place and therefore have a right to occupy it. This view not only disregards past injustices, but also imposes a certain understanding of what it means to inhabit a territory that might not be shared by different groups of people (for example, nomadic ones). Lockean theories, on the other hand, adopt an efficiency view whereby the legitimate claimants of a territory are those who have interacted with the land in a value-enhancing manner. What counts as value, however, is measured in a culturally-specific way: namely, European/Euroamerican, thus discarding indigenous ontologies of land. Kolers then suggests a third approach. According to the criterion of plenitude, a place is full when it is distinct from others and internally diverse. When trying to sort out territorial disputes in Latin America (and elsewhere), he claims, each ethnogeographic community should try and show to the others how their ontology of land realizes the plenitude criterion, without imposing their own ontology onto others.

If one believes that there is such a thing as a basic right to subsistence, then one should accept that those who do not have a place to live have a right of necessity to claim one. In her article, "Las poblaciones callampas como expresión del derecho de necesidad," Alejandra Mancilla begins from this theoretical assumption to defend the view that callamperos (illegal urban settlers in Santiago de Chile, especially between the 1950s and 1970s) were claiming their right of necessity by establishing themselves in empty patches of land, whether privately or publicly owned. Their individual, organized actions may be seen, according to Mancilla, as founding the later struggle for minimal housing rights lodged by politically-organized groups. Similar movements in other Latin American cities and beyond may also be interpreted, according to the author, as an expression of the right of necessity.

Finally, Juan Javier Rivera Andía focuses on a specific indigenous group in Peru, the Quechua-speaking Cañarenses, to show how the state has consistently portrayed them as poor and how they reject this externally-imposed label. Located in a mineral-rich territory, the group's disadvantaged economic position is further entrenched by the presence of large transnational mining projects in the area, from whose benefits they are excluded. Rivera Andía notices the invisibility of this indigenous community for Peruvian society in general, which plays against their attempts to be respected as an indigenous group with a right to choose what development projects are carried out in their lands. 